\title{
TOWARDS THE VERY NATURE OF CAREER, CAREER GUIDANCE AND COUNSELLING
}

\author{
C W T JOUBERT \\ F CROUS \\ Dept of Human Resource Management \\ University of Johannesburg \\ calliej@mweb.co.za
}

\begin{abstract}
The literature on career calls for a transformation and redefinition of career. In this paper we take a step back and ask: 'what is a career?'. Careers as works are presented; those entities that set up and formed the world in which humans live and have their being. In describing the characteristics of works and the way in which they set up and formed a world, we explicate the very nature of career guidance and counselling. In conclusion, we propose an approach by which practitioners can engage the world that is set up by a work.
\end{abstract}

\section{OPSOMMING}

Die literatuur betreffende loopbaan vra vir 'n tranformasie en herdefinisie daarvan. In hierdie artikel neem ons ' $n$ stap terug met die vraag: 'Wat is 'n loopbaan?' Loopbane as werke word voorgehou; daardie entiteite wat gestalte gee aan en die werreld konfigureer waarin menswees uitgeleef word. Deur die eienskappe van werke en die manier waarop hulle 'n wêreld konfigureer en vorm, voor te hou, verduidelik ons die werklike aard van loopbaanleiding en -voorligting. Ter sluiting stel ons 'n benadering voor waarvolgens praktisyns hulle kan besig hou met die wêreld wat deur 'n werk tot stand gebring word.

The world of work and career

There is a widely recognised perception that the world and business environments of most companies today change with incredible speed and that changes overwhelm both individuals and organisations. This perception led many to describe the world as unpredictable, turbulent, complex and confusing (Capra, 2003; Castells, 2000; Petzinger, 1999; Weick, 1995; 2001; Wheatley, 1999). If information overload, risk and technological complexity also enter the picture, it is reasonable to conclude that not only has interruption, shock and uncertainty become the normal human condition, but it is also the general condition and context within which career guidance and counselling are taking place.

That an increase in complexity has given rise to new work trends is also not new (Arthur \& Rousseau, 1996; Handy, 2001; Peiperl et al., 2000; Schreuder \& Theron, 1997; Walton \& Mallon, 2004). Changes in the world of work caused Handy $(2001: 6,12)$ to conclude that it is a new world we are living in, and "it is absurdly impractical to prepare oneself for the world as it was or as you would like it to be, when the reality is so different, and it is arguably immoral to educate others for a life that can't be lived as it used to be ...". In the wake of this understanding of the world and work, the literature on career not only registers a growing debate about new career forms and new ways of talking about career, but also the call "for a transformation and redefinition of career" (Walton \& Mallon, 2004, pp. 78, 90).

In this paper we take a step back and ask a very basic or 'prior' question: 'what is a career?' We take as our point of departure the assumption that no person can understand something unless that person has an accurate account of what it is that the person is trying to understand. It is our belief that an understanding of what a career is, can improve our understanding of the very nature of the activities known as career guidance and counselling which deals with, giving shape to and directing career as an entity.

To ask 'what is a career?' is not a scientific question, but an ontological question, since it pertains to and questions the very nature of the entity we try to understand. Despite all the contributions to this field of inquiry, the reader will not find a single explicit articulation of the ontological understanding of the very nature of career. What are found are models, theories and methods of the natural sciences to study human affairs (Greenhaus et al., 2000; Schreuder \& Theron, 1997; Stead \& Watson, 2004).

Requests for copies should be addressed to: F Crous, freddiec@uj.ac.za
As to the question of what career is, the literature answers in terms of definition or metaphorical descriptions. As a starting point in our argument, we will attempt to show that definitions and metaphors, however useful, are ultimately inadequate to answer the question of what career is, and thus why we need to answer the question. We will do so with the help of Heidegger. Heidegger's typology of entities gestures that career is an entity, called a work. We conclude by addressing the implications for career guidance and counselling of this assertion, 'a career is a work'.

\section{Definitions and metaphors used to understand careers}

The use of definitions and metaphors to understand career pose several problems. Walton and Mallon (2004: 90), for example, state that the defining of 'career' is a difficult process due to the multiplicity of disciplines and perspectives involved. In other words, it is difficult because there are as many definitions as there are perspectives. The following textbook definitions capture the conventional understanding of career:

"The sequence of employment-related positions, roles, activities and experiences encountered by a person" (Arnold 1997: 16).

"A career covers a sequence of positions, jobs, or occupations that one person engages in during his or her working life" (Cascio, 1991, p. 190).

Not only is 'career' often used as a synonym for 'career history' (as seen, for example, on an individual's curriculum vitae), as something that reveals a person's career 'progress', development, stability (wrongly linked to psychological stability) and change, but is it also noteworthy that 'career' is not deemed appropriate to apply to people who move in and out of jobs with apparently random job changes (Kidd, in Warr, 2002, p. 178). Such a career is presumed to lack coherence. Given the changing nature of our world, high levels of unemployment in the absence of available jobs, unexpected retrenchments over which people have no control and the reality of Handy's conclusions, the question is whether this picture of what is deemed to constitute career, can still be legitimately applied without doing substantial harm to job seekers?

To the question as to how a particular career is to be studied, the literature points in the direction of sequences of job titles or occupations (Kidd, in Warr, 2002, p. 178). The career (the whole) is thus reduced to and interpreted in terms of a few operational parts. It follows then that what a career is, is to be found in positions (status), job titles (importance) and work experiences over a person's span of life. But is there not 
something more, vitally important, missing from this standard textbook picture or definition of career? As Heidegger (in Sadler, 2002, p. 47) puts it:

“... a definition is precisely what is least suitable for grasping an essence [nature]. It is not a matter of capturing this essence [of what career is] in sentences (or in a single sentence) that we can repeat and pass on. The sentence as such says least of all".

As an alternative to the standard textbook definitions that has been pressed upon the minds of people for many years, we might well revert to the use of metaphors to understand the very nature of career. Whereas the importance of metaphor is generally recognised as a particular way to describe a phenomenon that is otherwise obscured, it is also true that it conceals at the same time that it reveals. In other words, it is not something that can be literally applied. As Morgan (1997, p. 4) points out, it can only provide a partial picture and, if taken literally, it becomes absurd. Consider the following examples.

1. Material or physical object as metaphor for career. To describe or define a career as a physical object causes people to think of career, including the human being and the work experiences related to it, as an object of scientific thinking. It is of course possible to think in this way about career, because people and the products of their labour do have physical manifestations. However, to use 'vehicle' (Power, 1988, p. 72), for example, to describe career is to press upon us images of planning, design, engineering and management, as something that can be constructed, analysed and studied like a machine.

"The use of machines has radically transformed the nature of productive activity and has left its mark on the imagination, thoughts, and feelings of humans throughout the ages. Scientists have produced mechanistic interpretations of the natural world, and philosophers and psychologists have articulated mechanistic theories of human mind and behaviour. Increasingly, we have learned to use the machine as a metaphor for ourselves and our society and to mold our world in accordance with mechanical principles" (Morgan, 1997, p. 12).

It is revealing that the word 'career' derives its meaning from two Latin words, "carraria (via) (road) for carriages" and "carrus" (wagon) (Colliers Dictionary, 1977, p. 149). As such, it refers to an entity that serves a particular purpose, that is, to carry a passenger toward a predetermined destiny. The Oxford Dictionary (1983, p. 475) gives us the following meaning of 'passenger': " a person (other than the driver or pilot or member of a crew) travelling in a vehicle or ship or aircraft; a member of a team or crew who does no effective work" (emphasis added). If 'work' is taken to mean "physical or mental exertion directed toward a definite end or purpose; labour; that which people do to earn a living; as something that needs to be done; undertaking; project and that which is being accomplished or produced" (Colliers Dictionary, 1977, p. 1146), then the image of career as vehicle breaks down because of the passivity implicated by the word 'passenger'.

It is worth noting that with the notion of career as 'vehicle', the notion of 'career path' made its appearance, meaning 'a sequential [upward] pattern of jobs', viewed as 'objective descriptions of sequences of work experiences' as opposed to subjective feelings (Cascio, 1991, pp. 242-243; Schreuder \& Theron, 1997, p. 17). While there has been significant criticism of career theory's tendency to dichotomise (Walton \& Mallon, 2004, p. 78), this notion of 'objective' and 'subjective' has another very damaging dimension to it: when 'objectively' viewed by an outsider, the meaning allocated to someone's career becomes divorced from the meaning the participant attaches to particular work experiences. Not only is the question who can describe the meaning of career, but also whether 'objective descriptions' can be divorced from the subjective feelings of the one doing the description?

2. Non-human organisms as metaphor for careers. The use of biological metaphors and analogies to study entities has become a popular and preferred way of thinking and talking about studying entities. This is especially evident in the social sciences, systems thinking and complexity theory. In the area of organisational theory, Morgan (1997) notes that over the past sixty years, mechanistic visions have caused many organisational theorists to use biology as a source of ideas for thinking about organisations and phenomena related to it. "In the process, organisational theory has [itself] become a kind of biology..." (p. 34).

To describe career as an 'octopus' (Power, 1988, p. 72), for example, is to suggest two things: (1) career is a living entity that lives in and interacts with an environment through a process of interpretation or other cognitive processes, and (2) the interplay of parts form the entity. Hence, references to career in literature as 'career systems' (Weick, 2001, pp. 208-209) as 'self-designing systems' and the 'need' inherent to such systems to continually update itself, as a significant source of adaptation. Understanding career in those terms are problematic, for it seems that purpose, intentions and the ability to learn are assigned to the system and not human beings.

To view career as a non-human organism that adapts to its environment certainly opens up thinking about career in ways machine metaphors do not allow, but clearly, it is indelicate to suggest that a career can 'live' in an environment the same way an animal or tree does. While systems theory may provide the 'insight' that the whole is more than its parts, it is also clear that parts in a career do not relate to each other in the way they do in humans.

3. The human being as metaphor for career. The literature on careers reflects another tendency by theorists, namely, to anthropomorphise career and in so doing, understand and explain career in terms of the psychology of human beings. Such tendencies are evident, for example, in descriptions of career as a 'self-designing (self-organising) system' that has the inherent ability to 'update itself' (that is, by 'continuous learning'), the 'boundaryless career being able to enact the boundaryless organisation' (Weick, 2001, p. 208-209) and 'careers as repositories of knowledge' (Bird, 1996). Although these ways of talking about career include reference to the human element that is very important in itself, the impression it leaves is not only that the career can do things that humans do, but also that they can do these things separately from the human. The question remains, however, whether they get any closer to an understanding of the very nature of career? Is it possible for a career to self-organise the way a person's metabolic system can? Can a career learn anything and so build know-how that can then be used to create poetry? What about 'career management'? Can a career be controlled, ordered and trained the way an animal can be controlled or trained? Or is the underlying implicit and indirect understanding not perhaps that 'career management' refers to the control and ordering of the person in accordance with a predetermined set of goals or 'career path'?

Hall and Mirvis (1995, p. 333) argue that, because of imminent changes in the world of work, careers have to become more 'protean'. The term protean here is taken from the Greek god Proteus, who could change at will. Again, is career an entity vested with will? It seems that Hall and Mirvis are actually telling us, indirectly, that people have to develop more flexibility in their work repertoire, that is, the ability to move among and within jobs, professions or occupations. What this tendency to anthropomorphise underscores is, however, that humans 
can only understand that for which they already have some sort of background that allows them to interpret and reinterpret their environment.

All three cases show that career is something: an object, an organism or a human being. What they also show is that the use of metaphor is neither intended to hold under all circumstances nor is it to be accepted comprehensively when applied to career. Nonetheless, if used frequently enough it can acquire the status of fact and does it lead to particular ways people see the world. The machine and organism metaphor treat people, for instance, as 'resources' that have to 'fit into' an organisation the way parts fit into a machine. Is it any surprise that Parsons (1909), considered to be the 'father' of psychometric testing, produced the notion of 'personenvironment fit' as the main construct for career decision making, at roughly the same time that Taylor (1911) and Fayol (1916) revealed 'scientific management' and 'general management' theory respectively? As Kidd (in Warr, 2000, pp. 181-182) pointed out, it was from this time that thinking about occupational choice was increasingly dominated by the assumed need to generate valid and reliable data about individuals and jobs. Psychometric tests were developed, first to assess aptitudes and later occupational interests.

It should be apparent that physical object, non-human organism or human metaphors are limited to being only metaphors, that different schools of thought are based upon the use of different metaphors as a foundation for inquiry "through which theory and research can be conducted" (Morgan, 1980, p. 607). If a human being, for example, is thought of as a rational animal, then theories will develop that befits the underlying presuppositions. However, if this theory turns out to be superficial, all hard work will have been in vain. Because all metaphors and theories are strongly paradigmatic (Beach, 1997) and, therefore, rooted in different realities (Berger \& Luckman, 1966), they give rise not only to different ways of thinking and talking about career, but they also have different implications for career guidance and counselling.

From our discussion thus far, we conclude that understanding career in terms of the standard textbook definition, that is, via its operational parts, does not yield a good understanding of career. As Heidegger (1993, p. 148) puts it, "a thing is not merely the aggregate of traits, nor an accumulation of properties by which that aggregate arises. A thing ... is that around which the properties have assembled" (emphasis added). Whereas the use of metaphor illustrates and allows for fresh perspectives on how to deal with or conceptualise career, it does not answer the question of what career is. One implication of metaphorical descriptions of career is, of course, that careers are never studied as they actually are, that is, as entities in their own right.

Our aim is thus to achieve an understanding of the very nature of career, as that entity around which operational aspects are assembled. We suggests that a better understanding of career is gained by thinking of career, not in terms of metaphor, or in terms of its constituent parts or characteristics, but as a particular type of entity, that is, the way it actually is. We propose that this entity can be called a Work. It follows that actions available to career guidance and counselling practitioners can be altered by the way in which they understand career.

\section{Works and world}

We encounter several entities that do not primarily exist as a physical manifestation, yet which are real. Examples would be philosophy, poetry, religion, symphonies and the laws of physics. Heidegger (1993) refers to such entities as works. World serves as the key concept along which Heidegger (1993; 1995) distinguished different types of entities and their way of being. Physical objects are characterised as 'without world'; no possibilities exist, for example, for the stone. They lack access to themselves or an environment. Thus, to be a thing without a world is not something amiss, since it has never been a realisable possibility in the first place.

Because non-human organisms react 'instinctively' in a stimulus-response way to disturbances in their environments, as they are genetically 'programmed' to react, they relate to their habitat in a 'dazed' way. It is dazed because they lack language, the capabilities to interpret things the way humans do, reflect on its own condition or think about future possibilities of living. They are accordingly characterised as 'world-poor' (Heidegger, 1993, pp. 212, 229-230; 1995, p. 236).

It is 'openness-for-being' and 'openness-for-world', that is, the human being's ability to form and shape a world, which principally distinguishes human beings from physical objects, animals and plants (Heidegger, 1977; 1995). Humans have world by virtue of 'being-in-world', and form world by virtue of being open-for-world. In other words, 'world-forming' does not refer to something like a programme, as something that a person can pick up on a Monday, drop on a Wednesday and take up again on the Saturday. Human beings are always in the middle of something and for this reason is the project of forming world something that belongs to the very nature of human beings and can therefore not be seen as an occasional activity.

"The human being as human being is world-forming. This does not mean that the human being running around in the street as it were is world-forming ... The Dasein [openness-forbeing] in the human being forms world: (1) it brings it forth; (2) it gives an image or view of the world, it sets it forth; (3) it constitutes [makes it what it is] the world, contains and embraces [grasps] it" (Heidegger, 1995, p. 285).

Works are characterised as entities that set up and open up a world (Heidegger, 1993, p. 170). However, world here does not refer to the sum of all observable objects or things, or of one object inside another (as in Cartesian dualism). It refers rather to what we read in the newspaper, for example, when the 'world' has been torn by conflict and strife, meaning the world of international relations, or the 'world of a mathematician', meaning 'the realm of possible mathematical objects' (Heidegger, 1962, p. 93), or the 'world of careers, career guidance and counselling', meaning the realm of care, possibilities and possible practices relating to another human being's way of living in a meaningful and significant whole.

It is thus a world that provides a frame of reference on which people 'place' the several objects that confront them in experience. Such an understanding of the world projects a human frame of reference upon phenomena and categorises them in accordance with this frame of reference. World is the ultimate reference point, which means the referential and significant whole within which practices have meaning and human beings can make sense of events, things, interruptions, animal and plant life, including themselves.

It is therefore world that permits for the possibility of 'a world' in the first instance. It follows that whatever presents itself to human beings in the world is seen as something. In the world of carpentry, a carpenter's drill shows up to drill a hole into wood or fixing a broken staircase. Similarly, in the world of a carpenter, wood shows up as an opportunity to build a number of house roofs, while in the world of the cabinetmaker the same wood shows up as an opportunity to manufacture wall units. Because the carpenter and the cabinet-maker live in two different worlds, the wood shows up as something and is thus intelligible to both. This interpretation contrasts with the Cartesian notion of a world that is already "out there". The world "worlds, and is more 
fully in being than the tangible and perceivable realms in which we believe ourselves to be at home. World is never an object that stands before us and can be seen" (Heidegger, 1993, p. 170). In other words, it is world that shows things the way they are, and what things show up as is what Heidegger (1962, p. $256 ; 1993$, p. 187) refers to as truth and actuality. It can thus be said that a work works when it worlds.

Because works are created and "gives to things their look and to human beings their outlook on themselves" (Heidegger, 1993, p. 168), the next section will focus on lifework to explain the entity called 'career'. The aim will be to show that lifework is an expression of who and how it essentially is, instead of a mere metaphorical description of it. In other words, the argument is that lifework, the work of every human being, is a work of being that sets up a world.

\section{Lifeworks}

Whereas 'life' usually refers to biological life or people's business, social or pleasure activities (Oxford Dictionary, 1983, p. 376), 'life' as used here, denotes a person's way of Being rooted in a particular quality of existence (Colliers Dictionary, 1977, p. $590)$, in the sense of over a person's 'span of life'. Work refers to the realm of working, that is, that which works. This is no small matter, because it is easy to fall into an unfit interpretation of the nature of the working. Heidegger $(1977$, p. 159) says:

"'To work' means 'to do'. What does 'to do' mean? The words belongs to the Indo-German stem $d h c ̧$; from this also stems the Greek thesis: setting, place, position. This doing, however, does not mean activity only; above all it does not mean activity in the sense of action and agency".

Since 'working' is, according to Heidegger, a doing, and unrelated to the human activities of producing - things like houses, tools and pictures, and work activities such as sewing, brewing or weaving, it does not have a connotation with 'efficiency' and 'effectiveness'. Heidegger locates the 'doing' of something in its Wesen (1977, p. 161) and means "that something comes to stand and to lie in unconcealment [truth]" (1977, p. 160). 'Work' comes from the Greek word ergon, which is a self-bringing-forth into full presencing; ergon is that which is the genuine and highest sense presences [an-west] (1977, p. 160).

Because Wesen has the same word as währen ('to last' or 'endure'), lifework thus denotes the meaning of a true, authentic and enduring work over every person's span of life. As such, it means neither a theoretical object nor a theoretical way of life (bios theõretikos) in the eye of an 'objective' beholder, or bios praktikos, the way of life dedicated to action and productivity. 'Beholding' such a work is, in its purest form as thinking, the highest doing. It beholds the openness-for-being in which the human being exists. We will briefly consider Socrates and Goethe from whose lives we can gain understanding of the notion of lifework.

In 399 B.C., three Athenian citizens brought legal proceedings against Socrates. They had accused him of failing to worship the city's gods, of introducing religious novelties and of corrupting the young men of Athens, and such was the severity of their charges, they had called for the death penalty. Though afforded an opportunity to renounce his philosophy in court, he had sided with what he believed to be true rather than what he knew would be popular. In Plato's account he had defiantly told the jury:

"So long as I draw breath and have my faculties, I shall never stop practicing philosophy and exhorting you and elucidating the truth for everyone that I meet ... And so gentlemen ... whether you acquit me or not, you know that I am not going to alter my conduct, not even if I have to die a hundred deaths" (De Botton, 2000, p. 4).
Why was he so hated? It could neither have been for his appearance (for few appreciated his looks), nor for something he has written (for he left no writings). Socrates practised philosophy. De Botton (2000, pp. 14-15) states that Socrates' most curious feature was a habit of asking his fellow citizens to explain why they had certain beliefs and what they took to be the meaning of life. He attempted to trap them into giving an account of their present life-style and the way they have spent it in the past. For that he was described as a 'gadfly', because he 'stung' where it hurts. But what was it he was trying to do? He wanted to tell his fellow citizens that the unexamined life is not worth living and that it is all right to question the status quo, for in the city of his day, the opinion of the majority was equated with the truth. The topics he discussed may be dated, but not the underlying moral: other people may be wrong, even if they are in important positions, even if they are espousing beliefs held for centuries by vast majorities. Soon after the philosopher's death the mood in Athens began to change.

The philosopher had predicted that Athens would eventually see things his way, and it did. He may have been a 'pain in the neck' for some while being alive, but through his doing of philosophy and his death, he opened up the world of Western civilisation through the writings of Plato that were to follow. This short description of Socrates' lifework makes it clear that a work does not present an overt obviousness. It may perhaps be said that its truth is (almost always) negative in its first appearance.

A study of Goethe's lifework shows that nothing was too important for him to turn his hand and mind to. Not only did he study law and became Minister of Education and the Chancellor of the University of Jena, but he was also Director of the court theatre. Schweitzer (in Joy, 1961) describes Goethe as a natural scientist, poet, thinker, savant, a person of action, who loved research and for whom justice was an abiding concern all through his life. He not only made music, drew and paint, but also engaged in activities such as engraving, woodcutting and etching. From the point of view of the standard textbook definition of 'career', Goethe's lifework would have been looked at from the perspective of 'paid employment'. However, for Goethe it would have meant a carving up of his life, something he would have viewed with disdain, for he considered his lifework as a complete whole. In light of this anyone can rightfully ask, if somebody is employed as a domestic worker, but is also head of a youth group and a sculptor, would it be correct to view her lifework mainly in terms of her paid employment?

What is important to note is that Goethe "constantly transformed not only himself but everyone who came within the orbit of his life and work" (Friedenthal, 1993, p. 19). For him, it was through action that people best give an account of themselves. To the question of how a person can best understand him/herself, Goethe replies, "Try to do your duty and at once you will know what kind of [person] you are". What is duty for Goethe?

What everyday wishes you must ask.

Each day will tell you, this your task.

Take pleasure then in what you do;

The work of others honor too.

Let no man ever make you hate;

For all else to God entrust your fate.

To self be true, and true to others ... (in Joy, 1961, p. 52)

According to Heidegger (1993, p. 168) all works have an arresting presence, something that stands out as striking. Some things, such as new hairstyles, stand out from the ordinary merely because they are cleverly designed and innovative, but these are fads that attract curiosity momentarily and then pass away. A work, in contrast holds people's attention at a level that goes deeper than curiosity; it demands time and reflection. As such, in other words, lifeworks as works do not present an obvious 
message; they require interpretation. However, lifeworks as works, are interpreted not in terms of private inner experiences they evoke or elicit, but the works itself. What attracts attention then, is what works do; what they open up for human beings to see and allow other people to share in.

What is manifested in their lifeworks, are the "truth of beings [that] has set itself to work" (Heidegger, 1993, p. 162). Works have the power to make people truly notice the being of beings, instead of taking it for granted, and have the power to bring forth the being of all other beings. As original works, they thus have the power to transport human beings out of the realm of the ordinary and touches them in a way the "shopworn being of things does not" (Polt, 1999, p. 135). As works, they are concerned with bringing hidden truths out into the open.

Lifeworks, as works, speak on their own terms; they say something only they could say. They let people see who they are, have been and can be. It reveals something of a how and who-being, for example, (1) a human being (as opposed to as a 'thing'); (2) the carpenter's way of being; and (3) people's way of living. In terms of Heidegger's (1977, p. 159) thinking, "one is what one does. That which 'does' in such a sense is that which works".

Another aspect a lifework draws attention to is captured by Heidegger's (in Dreyfus, 1991, p. xi) concept of Ganzheit, rendered as 'totality' or 'whole'. What it drives at is the opposite of a 'separatist mindset', that is, a compartmentalising of one's living or a split between who/how a person is and what a person does, hence, a split between 'inner' and 'outer', or private and public. What works thus demonstrate is a unity of living, life lived as a whole. This seems to suggest that if people think of the totality as constituted of independent fragments, then that is how they will tend to live and operate, but if they could include everything coherently, as undivided and unbroken, and without a border, then their lifework as a work will tend to move in a similar way, and from this will flow an orderly action within the whole. In other words, people's general way of thinking of the totality is crucial for overall order of their lifeworks as works. Thus, in taking a stand on their way of being, their lifework as a whole, a split of the whole into fragmentary and unrelated parts has no place. It would therefore be improper to say, for example, "do not mix work and pleasure", or "do not let your private life interfere with your public work-life".

If lifeworks as works are to be considered abstract entities, then this means that it permits a proper comprehension neither of existence or the human being's world or lifework as a whole. For to define lifeworks in terms of employment related work experiences and activities is to bracket a person's way of being into parts that makes understanding of the whole impossible. This is a crucial mistake. A person is (teacher) because of what she does (teaching). In other words, 'teacher' does not define or determine the teaching in the first instance; it is the teaching that makes her a teacher. Similarly, a person is not a leader simply because that person has a certain position or title; it is the actions that define the person as leader. However, if the teacher stopped teaching two hours ago and engages aeroplane flying now, can it still be said she is a teacher, or is she a pilot now?

Segmentising (bracketing) a person's lifework into bits is thus to deny human beings a world, a coherent and referential whole. For every activity the human being engages in, including employed work (for example, secretary or gardener), provides a context or world in which people encounter themselves as who they are. To view a person's lifework only in terms of employed work experiences is thus to mistake a derivative mode of being for the significant mode of being (existence). Heidegger (1962, p. 33) calls it 'derivative' because it comes into focus when people disregard the referential totality of those practical and personal concerns that make up the everyday world.
A stone is; the human being exist, that is, it has the ability to 'stand out' in contrast to mere lying around. It follows that self-interpretation and understanding are unique characteristics that only belong to the existent human being. The human being is thus "ontologically distinctive in that it is ontological". With the distinction between the ontical and the ontological, Heidegger draws attention to the difference between two ways or modes of existence and two ways of understanding a human being. The first, the ontical, refers to the level of the empirical sciences, such as psychology, which concerns itself with empirical properties and factual explanations of the human being (Philipse, 1998, p. 17) and that which concerns beings in everyday existence, for example, such as a job and worries about how to pay off debts. On this instrumentalist level, everything is approached as a means to an end. It is momentary and segmentary, and refers to occupations in an establishment that keeps people busy by means of a 'carrot-stick' methodology (Guignon, 1993, p. 230). In this way of living, everything a person does is in order to get something; it is episodic, and hence lacks overall purpose and significance. They are activities that a person would avoid if it were possible to do so. Heidegger refers to this as an 'inauthentic' way of being.

The ontological, in contrast, refers to that which concerns ways or modes of being, which manifests a lifework (that may include jobs, in the sense of earning money in order to live, although the motive of wealth is not its primary concern). On the ontological level, actions are not just routes in themselves, but they are 'for-the-sake-of-being' in some specific way, that is, the actions and the doings are part of being a person of a certain sort. The point is, although the actions are the same in both cases, the quality of living will be different. Ultimately it is a choice; a person can choose to live on the ontic level and interpret him/herself as things to be used by others and who only operate on the means-end scale, or can choose a mode of living which means a way of acting and doing for the sake of being a person of a certain kind. The latter mode of being Heidegger calls 'authentic' living.

A student of physics, for example, is not simply learning facts about the material world, but is learning how to do physics - the student is becoming a physicist. Thus, the physicist student is best understood, neither in terms of a seeking of innate abilities in him/herself nor as accumulating facts about the world. In Heideggerian terms, the student is learning how to go about in the world in a certain way, for instance, as a physicist or medical doctor. In other words, what the student is, is inseparable from what $s /$ he does.

Understanding is thus more primordial than the disclosure of possibilities. Focusing on the discovery of facts (psychological needs, interests, values and preferences) of oneself will obscure the dimension of disclosure. Indeed, it is disclosedness (the way of a person's as - hermeneutical as) that makes discovery possible in the first instance. Discovery of one fact after another would not generate understanding of a world that is meaningful and significant, but only a disconnected aggregate. Understanding is thus about relations and situations in a meaningful whole.

Lifeworks, as works, are world-transforming events; it gives people (and those who share in that world) a coherent focus and direction for their lives. In other words, a work is also a worlddefining work. It gives entities its identity, that is, a who and how they are. It also tells people what is at stake, what is measureless, what is not yet mastered and what is still concealed and confusing - thus in need of a decision. Through the work, the "dawning world brings out what is as yet undecided and measureless, and thus discloses the hidden necessity of measure and decisiveness" (Heidegger, 1971, p. 63). 
Heidegger (1971, p. 70) stays that because truth always happens through being articulated or composed, all works are essentially poetry, in the broadest sense of the term. Because poetry speaks, articulates (makes things intelligible), opens up (reveals), calls into being and put things up for decision (for example, worthy and unworthy causes), it can initiate a new beginning for a people.

"A great work of art therefore can inaugurate a new beginning for a community. What before had been humdrum and self-evident suddenly stands forth as strange and challenging as a result of this reconfiguration of the world: the work contains 'the undisclosed abundance of the unfamiliar and the extraordinary, which means that it also contains strife with the familiar and the ordinary'" (Heidegger, 1993, p. 23).

It thus plays the role of founding (denoting an origin) and defines the tasks for future preservers whose world has been opened up by the work. In other words, this discussion of lifeworks leads us to lifework guidance and counselling. If we accept that a career is a lifework, then the art and science of creating, attending to and assessing a lifework must be the very nature of lifework guidance and counselling.

Stewardship as a work that creates and preserves a lifework Acknowledging a career as a lifework provides us with a new starting point for thinking about the task of creating and preserving a lifework, a task that is referred to as 'career guidance and counselling', which stems mainly from the field of 'vocational' (Brown et al., 1996) and 'organisational' psychology (Arthur et al., 1989). The image of the guidance and counselling practitioner that derives from this literature can be described as that of the detached scientist, observing phenomena in an objective manner, in accordance with which phenomena can be designed, planned, managed and developed in a predictable way. For Heidegger (in Lovitt, 1977, p. 14), with science the objectifying of everything began the kind of revealing that dangers the very nature of what it means to be a human being. Not only is it geared to the purposes of manipulation and control, but it is also providing the blueprint for transforming the world into sheer resource or mere equipmentality (means-to-an-end).

In the world of science, whatever is quantitatively analysed and scientifically processed has credibility and whatever escapes calculation is eliminated (Morgan, 1997, p. 240). This becomes evident in pre-employment 'personality profiles' and measurements according to which people are judged and reinterpreted for the purposes of determining suitability for jobs and predicting the possibility of later movement, and career succession and planning according to predetermined career paths and organisational 'charts' ('organograms'). What is left out of the equation is the spirit of the human being. It is therefore no surprise that one critic refers to the human relations school of thinking and 'industrial' psychology as "the maintenance crew for the human machinery" (Kanigel, 1997, p. 17). The most damaging effect is the possibility of failing to recognise works as works, which in turn means a failure to help others creating true and original works to set up a particular world.

In contrast to technique that makes things to happen in cause and effect terms, we propose stewardship as a work of art that does not manipulate or move things in a physical sense. Creating is first and foremost bringing-forth the unconcealment of being in the work (Heidegger, 1993, pp. 159, 197). Works show entities in a whole new way; they affirm their very nature in a way that was previously unknown. This means that thinking is not divorced from action. Just as the philosopher cannot think philosophy without practicing it, so the artist cannot think the painting without seeing it. In other words, stewardship requires presence in the lifework.
Thus, rather than viewing lifework in a detached manner, it means a process of participation and world-creation. Instead of operating on a lifework, it functions within the world that is set up by the work, that is, the referential and significant whole. This means that it is essentially a sensemaking process (Dreyfus, 1991, p. 10; Weick, 1995), an ongoing process of making sense of that which people are already in and in which they want to be. In other words, it is a process of working out references, uncovering the meanings that they give and understanding how the work hangs together as a whole. Because stewardship is a work and therefore a lifework too, it works when it worlds.

Since sensemaking is about the world (Weick, 1995, p. 132), in the following sections we suggest three questions that can direct career counsellors' ('stewards') efforts in order to meaningfully engage career counselees ('journeyers'), which can ensure a satisfactory, authentic and more or less safe journey through life.

\section{What Kind of World Would You Like to be in?}

This question does not relate or refer to the standard interview question posed to a job applicant of, namely, "Where do you see yourself in five years time?". The question has nothing to do with occupation, position or business organisation. Neither does it refer to a personal 'vision'. It rather relates to the issue of lifework that refers to and suggests everything the lifework sets up, give shape to and is to share in, in an indirect way. This question takes the journeyer back to Socrates and Goethe, human beings who have made something of themselves and whose lifework provided things with a look and human beings with a certain outlook on themselves in truth or unconcealment. It is a question that relates to the mode or way of one's Being and the impact and enduring influence thereof upon others. In other words, it places journeyers before the fundamental question of their existence about whether they wish to stand out or merely lay around (and be treated like a thing).

Asking about the world thus leads to a re-examination of one's self and the quality of one's actions. Put differently, taking world as a point of departure would allow for an examination of lifework and, by so doing, uncover the lifework as it now is and as it can be. It also means, by implication, that a lifework can be assessed through looking at what its world does for human beings. Is it a world that elicits fear from people or is it a world that constantly draws people into its ever expanding horizons?

\section{What Will You Allow in that World?}

Of course a person's lifework is not without actions. Engagement with any world is about actions being taken in that world. Therefore, to have impact, the actions have to be of a certain kind. Irresponsible and inconsiderate actions that harm the dignity of human beings may not yield the results a person is looking for. In other words, a person is a parent, a teacher or leader because the person engages in activities that reveal who (and how) the person is. Seen in this way means assessment starts with actions rather than cognitive processes and identification of temperament or personality types. It also means that a person will only know whether actions taken and decisions made were correct after the fact of having been taken or made. In other words, to make sense of one's actions is a process that works in retrospect and it is ongoing.

Actions will therefore have to be taken in accordance and consistent with the message to be communicated by the lifework. It means that actions cannot be taken in a carefree manner, or without limits, or out of character. Because journeyers are confronted with various maps and routes to certain sure destinies, all the while promising 
various benefits and privileges on arrival, they will have to read the 'signs' on a particular road very carefully and ascertain whether they are consistent with the world they wish to establish. If 'maps' here are understood in a metaphorical way, then it is clear that not all routes 'lead to Rome', so to speak.

Being en-route means travelling under constraints. It is these very constraints that sometimes draw people to lifeworks in the first instance. In other words, self-imposed constraints are definite features of identity, for example, a refusal to engage in discriminatory practices or treating people as disposable parts in a machine.

3. What Actions Will Uphold and Sustain Your Lifework as an Original Work that Sets Up a World?

If our age is indeed what an increasing number of people describe as the 'information age' (Castells, 2000; 1997; 1998), if uncertainty and turbulence have indeed become the essence of the contemporary scene, then it is reasonable to say that flexibility and innovation are two requirements for living in this world. Through continuous learning the journeyer can make this capacity possible and enrich him/herself. Learning is outward looking, mind opening and promotes tolerance, respect and understanding of others. To learn means that responsibility and ownership lie with the journeyer.

Learning is, however, also a partnership; it requires interaction and is only truly enjoyable and fruitful if it yields results to the benefit of other people as well. Assessment of a lifework will therefore confirm progress rather than brand failure. Partnership is one way to attend to a work. A partner can serve as a sounding board, as guide on a person's journey; a partner strengthens independent judgement in the face of a majority and enlarges the pool of data that are considered. Partnerships are likely to endure if they build on mutual respect, trust and honesty, which will not allow for the deprecating of others or oneself. In the final analysis, any action is allowable, provided it is not inconsistent with the work the journeyer wants to set up, shape and share with others.

\section{CONCLUSION}

These questions points towards a way by which stewards can create, shape and give direction to a lifework. Providing blueprints for action is an impossible undertaking, since there is no sure way of bringing-forth extraordinary works. However, asking and answering these questions is an ongoing process. In the world of work (jobs) the focus and attention shifted toward externalities, as the main (sometimes the only) source from which people derive meaning. We propose that people want something more. Implicit in our understanding of career is that, that 'something more' is not work (mere employment activity or a job), but a search for place and placement, that is, how people can make their lives work.

We proposed that every career is necessarily a lifework, a work of being; it always sets or opens up a world that serves as a source of inspiration, even if the world that it sets up is not one with broad appeal. To be on a journey does not mean to repeat the past or getting stuck into one place. It rather implies adventure and a creative process, full of surprises, interruptions and uncertainties. It is therefore something people are at liberty to determine; they do not have to be slaves of a so-called 'environment'. Understanding a lifework this way means that people have to mind their words and actions since they set up a realm of further possibilities pertaining to themselves and others sharing in it. A lifework, then, by creating a particular world, determines what is important.

\section{REFERENCES}

Arnold, J. (1997). Managing Careers into the 21 ${ }^{\text {st }}$ Century. London: Chapman.

Arthur, MB., Hall, D.T. \& Lawrence, B.S. (eds.) (1989). Handbook of Career Theory. Cambridge: Cambridge University Press.

Arthur, M.B. \& Rousseau, D.M. (1996). Introduction: The Boundaryless Career as a New Employment Principle. In M.B. Arthur \& D.M. Rousseau. The Boundaryless Career. A New Employment Principle for a New Organizational Era, 3-20. New York: Oxford University Press.

Beach, L.R. (1997). The Psychology of Decision Making. People in Organizations. Thousand Oaks: Sage.

Berger, P.L. \& Luckmann, T. (1967). The Social Construction of Reality. New York: Doubleday Anchor.

Bird, A. (1996). Careers as Repositories of Knowledge: Considerations for Boundaryless Careers. In Arthur MB \& Rousseau D (eds.). The Boundaryless Career: A New Employment Principle for a New Organizational Era, 150-168. New York: Cambridge University Press.

Brown, D., Brooks, L. \& Associates (1996). Career Choice and Development (3 ${ }^{\text {rd }}$ ed). San Francisco: Jossey-Bass.

Capra, F. (2003). The Hidden Connections. A Science for Sustainable Living. London: Flamingo.

Cascio, W.F. (1991). Applied Psychology in Personnel Management. New Jersey: Prentice-Hall.

Castells, M. 2000 (1996). The Rise of the Network Society (2nd ed). Oxford: Blackwell.

Castells, M. (1997). The Power of Identity. Oxford: Blackwell.

Castells, M. 2000 (1998). End of the Millenium (3rd ed). Oxford: Blackwell.

Colliers Dictionary (1977). New York: Macmillan Publishing Co.

De Botton, A. (2000). The Consolations of Philosophy. London: Hamish Hamilton.

Dreyfus, H.L. (1991). Being-in-the-World, A Commentary on Heidegger's Being and Time, Division I. Cambridge: MIT Press.

Fayol, H. 1948 (1916). Industrial and General Administration. London: Pitman.

Friedenthal, R. (1993). Goethe. His Life and Times. London: Weidenfeld.

Greenhaus, J.H., Callanan, G.A. \& Godshalk, V.M. (2000). Career Management ( $3^{\text {rd }}$ ed). Orlando: The Dryden Press.

Guignon, C. (ed.) (1993). The Cambridge Companion to Heidegger. Cambridge: Cambridge University Press.

Hall, D.T. \& Mirvis, P.H. (1995). Careers as Lifelong Learning. In A. Howard (ed.). The Changing Nature of Work, 323-358. San Francisco: Jossey-Bass.

Handy, C. (2001). The Elephant and the Flea. London: Hutchinson.

Hofstadter, A. (trans.) (1971). Poetry, Language, Thought. New York: Harper \& Row.

Joy, C.R. (trans.) (1961). Goethe. Five Studies by Albert Schweitzer. Boston: Beacon Press.

Kanigel, R. (1997). The One Best Way: Frederick Winslow Taylor and the Enigma of Efficiency. New York: Viking Penguin.

Kidd, J.M. (2002). Careers and Career Management. In Warr P (ed.) 2002 (1996). Psychology at Work, 178-198 (5 th ed). London: Penguin.

Krell, D.F. (ed.) (1993). Basic Writings. San Francisco: Harper.

Lovitt, W. (trans.) (1977). The Question Concerning Technology and Other Essays. New York: Harper \& Row.

Macquarrie, J. \& Robinson, E. S. (trans.) (1962). Martin Heidegger. Being and Time. Oxford: Blackwell.

McNeill, W. \& Walker, N. (trans.) (1995). The Fundamental Concepts of Metaphysics. Bloomington: Indiana University Press.

Morgan, G. (1997). Images of Organization. California: Sage.

Parsons, F. (1909). Choosing a Vocation. Boston: Houghton Mifflin.

Petzinger ,T. (1999). The Gurus Speak: Complexity and Organisations. Emergence, 1 (1), 75, 90.

Peiperl, M., Arthur, M., Goffee, R. \& Morris, T. (2000). Career Frontiers. New Conceptions of Working Lives. Oxford: Oxford University Press. 
Philipse, H. (1998). Heidegger's Philosophy of Being. A Critical Interpretation. Delhi: Motilal Banarsidass Publishers.

Polt, R. (1999). Heidegger: An Introduction. Ithaca: Cornell University Press.

Power, D.J. (1988). Anticipating Organization Structures. In J. Hage (ed.). Futures of Organizations, 67-79. Lexington, Mass.: Lexington Books.

Sadler, T. (trans.) (2002). The Essence of Truth. On Plato's Cave Allegory and Theaetetus. Martin Heidegger. New York: Continuum.

Schreuder, A.M.G. \& Theron, A.L. (1997). Careers. An Organizational Perspective. Kenwyn: Juta \& Co.

Stead, G.B. \& Watson, M.B. (eds.) (1999). Career Psychology in the South African Context. Pretoria: Van Schaick Publishers.
Taylor, F. (1911). Scientific Management. New York: Harper Brothers.

The Oxford Paperback Dictionary (1983) (2nd ed). Oxford: Oxford University Press.

Walton, S. \& Mallon, M. (2004). Redefining the Boundaries? Making Sense of Career in Contemporary New Zealand. Asia Pacific Journal of Human Resources, 42 (1), 75-95.

Warr, P. (ed.) 2002 (1996). Psychology at Work (5th ed). London: Penguin.

Weick, K.E. (1995). Sensemaking in Organizations. Thousand Oaks: Sage

Weick, K.E. (2001). Making Sense of the Organization. Malden: Blackwell.

Wheatley, M.J. (1999). Leadership and the New Science (2nd ed). San Francisco: Berret-Koehler Publishers Inc. 


\section{REVIEW PANEL EDITION 31.3}

Mr COK Allen-Ile

Prof J Coetzee

Prof M de Beer

Prof A Engelbrecht

Ms S Laher

Prof R Le Roux

Mr D Meiring

Dr W Naudé

Prof K Norum

Prof HJ Pietersen

Prof C Pottas

Prof S Rothmann

Prof W Schoeman

Mr D Steyn

Prof JS Uys

Prof TH Veldsman

Prof AM Viviers

Dr S Wolmarans
Fort Hare University

North-West University

UNISA

University of Stellenbosch

University of Witwatersrand

University of KwaZulu Natal

SAPS

North-West University

Gonzaga University

University of Limpopo

Emeritus Professor - University of Pretoria

North-West University

University of Johannesburg

University of Pretoria

University of Johannesburg

University of Johannesburg

UNISA

Learning Link

We apologise for inserting the incorrect review panel for edition 31.2 (2005). Please replace the review panel for Vol 31.2 (2005) with this one.

\section{REVIEW PANEL EDITION 31.2}

Dr N Bontis

Prof HE Brandt

Prof JH Buitendach

Dr M Coetzee

Ms A Crafford

Ms S Goodman

Dr L Griessel

Dr T Groenewald

Mr K Heslop

Prof C Hoole

Dr T Magojo

Prof S Rothmann

Prof T Ryan

Dr P Scholtz

Prof G Sieberhagen

Prof C van Tonder

Prof D Visser
Mc Master University

University of Pretoria

North-West University

UNISA

University of Johannesburg

University of Cape Town

University of the Free State

UNISA

University of the Western Cape

University of Pretoria

University of KwaZulu Natal

North-West University

University of Cape Town

North-West University

North-West University

University of Johannesburg

University of Johannesburg 